\title{
Strategies for Improvement of Soybean Regeneration via Somatic Embryogenesis and Genetic Transformation
}

\author{
Beatriz Wiebke-Strohm ${ }^{1}$, Milena Shenkel Homrich ${ }^{1}$, \\ Ricardo Luís Mayer Weber ${ }^{1}$, Annette Droste ${ }^{2}$ and \\ Maria Helena Bodanese-Zanettini ${ }^{1}$ \\ 1 Universidade Federal do Rio Grande do Sul \\ ${ }^{2}$ Universidade Feevale \\ Brazil
}

\section{Introduction}

The seed, which contains the embryo, is the primary entity of reproduction in angiosperms. In flowering plants, as in other eukaryotes, the embryo develops from the zygote formed by gametic fusion. However, during the course of evolution many plant species have evolved different methods of asexual embryogenesis to overcome various environmental and genetic factors that prevent fertilization (Sharma \& Thorpe, 1995; Raghavan, 1997).

Somatic embryogenesis (SE), starting from somatic or gametic (microspore) cells without fusion of gametes (Williams \& Maheswaran, 1986), is one form of asexual reproduction. This process occurs either naturally or in vitro after experimental induction (Dodemam et al., 1997), and is a remarkable phenomenon unique to plants. The process is feasible because plants possess cellular totipotency, whereby individual somatic cells can regenerate into a whole plant (Reinert, 1959).

SE has been observed in tissue cultures of several angiosperm and gymnosperm plant species, and involves a series of morphological changes that are similar, in several aspects, to those associated to the development of zygotic embryos. In soybean (Glycine max (L.) Merrill), histological sections of embryogenic structures can be found in some reports (Barwale et al., 1986; Finer \& McMullen, 1991; Kiss et al., 1991; Liu et al., 1992; Sato et al., 1993). A characterization of the developmental stages of soybean somatic embryos was performed by Christou \& Yang (1989), Fernando et al. (2002), Rodrigues et al. (2005), and Santos et al. (2006). The pro-embryo, globular, heart-shaped, torpedo and cotyledonary embryo stages were found, closely resembling the ontogeny of zygotic embryos. However, the absence of a characteristic suspensor, as well as the delay in the establishment of inner organization were the main differences between zygotic and somatic embryogenic processes (Santos et al., 2006). 


\section{Soybean somatic embryogenic process}

In general, the in vitro soybean somatic embryogenic process can be divided into different phases: induction, proliferation, histodifferentiation, maturation, germination and conversion into plants.

\subsection{Somatic embryo induction}

According to Sharp et al. (1982), the induction of somatic embryogenesis (Fig. 1 A1, B1, C1) can be considered as termination of the existing gene expression pattern in the explant tissue, and its replacement for an embryogenic gene expression program in those cells of the explant tissue which will give rise to somatic embryos. These authors used the term "induced embryogenic determined cell" (IEDC) to describe an embryogenic cell that has been originated from a non-embryogenic cell. Cells from very immature zygotic embryos, which already have their embryogenic gene expression program activated, were termed "pre-embryogenic determined cells" (PEDCs). For the purposes of regeneration, both terms may be referred to simply as "embryogenic cells" (ECs) (Carman, 1990; Merkle et al., 1995).

There is a major developmental difference among explants with respect to the ontogeny of somatic embryos. The obtainment of somatic embryogenesis in legumes depends on whether the explant tissue consists of PEDCs (for example, very immature zygotic embryos) or non-ECs (for example, differentiated plant tissues). In the first case, a stimulus to the explant may be sufficient to induce cell division for the formation of somatic embryos, which appear to arise directly from the explant tissue in a process referred to as direct embryogenesis (Fig. 1 A1, B1). In contrast, non-EC tissue must undergo several mitotic divisions in the presence of an exogenous auxin for induction of the ECs. Cells resulting from these mitotic divisions are manifested as a callus, and the term indirect embryogenesis is used to indicate that a callus phase intervenes between the original explant and the appearance of somatic embryos (Fig. 1 C1) (Merkle et al., 1995).

Thus, the somatic embryo induction process can be achieved using different approaches, as illustrated in Figure 1. Somatic embryos induced from very immature zygotic embryos (torpedo-stage) upon exposure to cytokinins were only obtained in clovers (Trifolium ssp.) (Maheswaran \& Williams, 1984) (Fig. 1 A). In soybean, somatic embryos can be induced in response to auxins, and regenerated directly from cotyledonary-stage zygotic immature embryos without an intervening callus phase (Lazzeri et al., 1985; Finer, 1988; Bailey et al., 1993; Santarém et al., 1997) (Fig. 1 B). Finally, some legumes, notably alfalfa (Medicago sativa), can be regenerated from leaf-derived callus (Bingham et al., 1988). In this case, the tissue responds to combinations of auxins and cytokinins (Fig. $1 \mathrm{C}$ ).

The type of growth regulator and explant, as well as genotype ability to respond to in vitro stimulus, are the main factors affecting somatic embryogenesis induction. The role of exogenous cytokinins during the induction phase depends on whether somatic embryogenesis is direct or indirect. When SE is originated from callus, the frequency of somatic embryo formation is enhanced by cytokinins. However, in direct systems, such as in soybean, in which somatic embryos are formed directly from immature zygotic embryos, addition of a cytokinin reduces the frequency of embryo formation (Merkle et al., 1995). Soybean SE is induced by two auxins: $\alpha$-naphthaleneacetic acid (NAA) and 2,4-dichlorophenoxyacetic acid (2,4-D), but the most commonly used is 2,4-D. The exact 
mechanism underlying the auxin-induced somatic embryo formation is not understood, but some studies with other legumes suggested certain auxin-induced cellular processes such as embryo-specific DNA methylation (Vergara et al., 1990), disruption of tissue integrity by interrupting cell-cell interaction (Smith \& Krikorian, 1989) and establishment of cell polarity (Merkle et al., 1995). However, auxins are not the only substances able to induce embryogenesis. Several other factors that alter gene expression programs (e.g., stress) or disrupt cell-cell interaction (physical disruption of the tissue) can also direct this transition (Gharyal \& Maheshwari, 1983; Dhanalakshmi \& Lakshmanan, 1992).

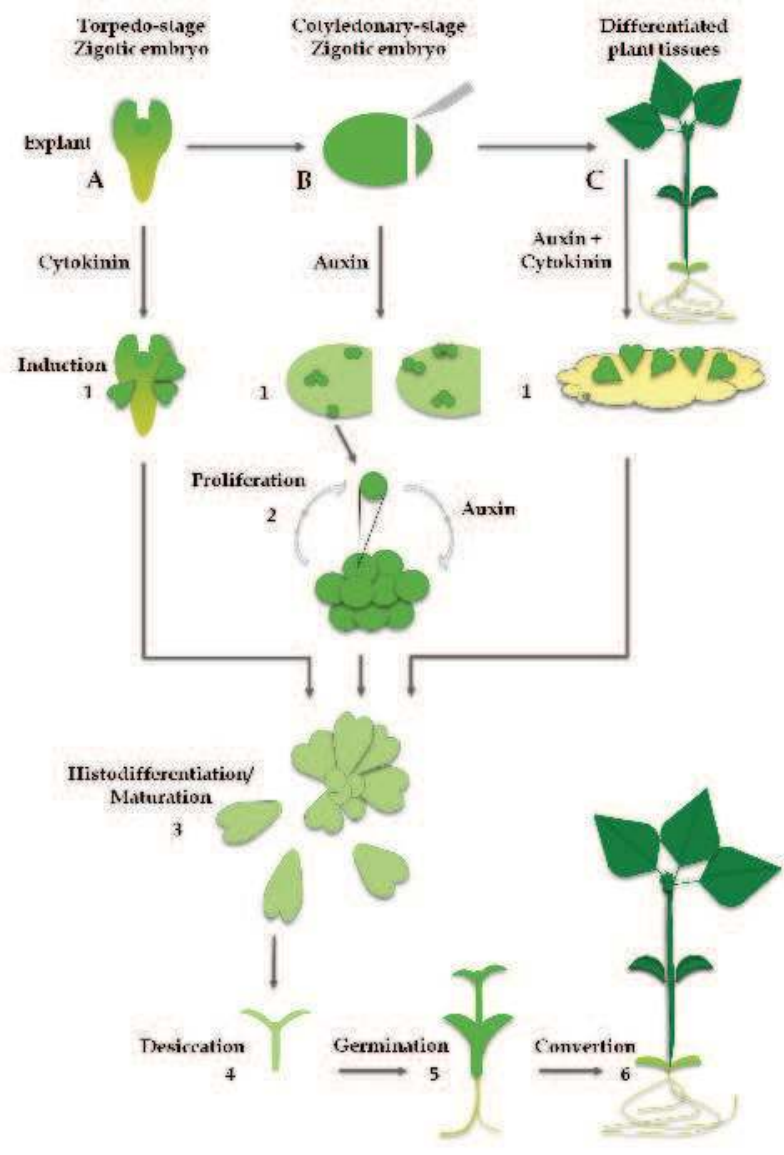

Fig. 1. Embryogenic processes in legumes. Somatic embryos may be induced (1), histodifferentiated/matured (3), desiccated (4), germinated (5), and converted into plants (6). Alternatively, auxin can be used to maintain repetitive embryogenesis - embryo proliferation (2), which continues until auxin is withdrawn from the medium, allowing somatic embryos to resume their development. (A) The youngest zygotic embryos respond to cytokinin; (B) older zygotic embryos respond to auxin, and (C) differentiated plant tissues respond to combination of auxin and cytokinins by forming callus. (Adapted from Parrott et al., 1995. Drawing by S. N. C. Richter) 
The choice of explant is a critical factor that determines the success of most tissue culture experiments. Immature, meristematic tissues proved to be the most suitable explant for somatic embryogenesis in legumes (Lakshmanan \& Taji, 2000). For instance, cotyledons of immature zygotic embryos have been the most used explants for the induction of SE in soybean (Lazzeri et al., 1985; Finer, 1988; Bailey et al., 1993; Santarém et al., 1997; Droste et al., 2002). However, in this species, somatic embryos have also been obtained from leaf and stem (Ghazi et al., 1986), cotyledonary node (Kerns et al., 1986), anther (Santos et al., 1997; Rodrigues et al., 2005) and embryonic axes (Kumari et al., 2006).

The last but not least important factor affecting somatic embryo induction is plant genotype (Merkle et al., 1995). In soybean, considerable variation in embryogenic capacity was found to exist between individual genotypes (Komatsuda et al., 1991; Bailey et al., 1993a, b; Santos et al., 1997; Droste et al., 2001; Meurer et al., 2001; Tomlin et al., 2002; Hiraga et al., 2007; Yang et al., 2009; Droste et al., 2010) as will be discussed below (Genotype-dependent response and screening of highly responsive cultivars section).

\subsection{Embryo proliferation}

A common characteristic of embryogenic tissue is that it can remain embryogenic indefinitely. This proliferative process has been variously termed secondary, recurrent or repetitive embryogenesis (Fig. 1 B2). In soybean, the primary somatic embryos can have multicellular origins, while secondary somatic embryos (i.e. originating from another somatic embryo) tend to have unicellular origins (Merkle et al., 1995). Hartweck et al. (1988) found somatic embryos originating from groups of cells in soybean zygotic cotyledons, while Sato et al. (1993) found embryos proliferating from globular-stage soybean somatic embryos that originate from single cells.

Proliferation of embryogenic cells is apparently influenced by a variety of factors, some of which are controlled during the culture process, and some of which are yet undefined. Some of the factors that have been investigated are also associated with induction phase, such as plant genotype and growth regulators (Merkle et al., 1995).

The most broadly documented factor associated with continuous proliferation of embryogenic cells is auxin. For soybean, secondary somatic embryo proliferation is possible if it is maintained in a medium containing the auxin 2,4-D (Finer \& Nagasawa, 1988). Single epidermal cells have been shown to initiate soybean secondary somatic embryos (Sato et al., 1993). The exact role of auxin in triggering proliferation is unknown. Furthermore, the level of auxin required to maintain repetitive embryogenesis depends on the culture protocol adopted.

\subsection{Embryo histodifferentiation and maturation}

After induction, somatic embryos start an ontogenetic development process similar to that of their zygotic counterparts (Merkle et al., 1995). The process of organ formation through which a globular-stage embryo develops into a cotyledon-stage embryo has been termed histodifferentiation (Fig. 1 B3) (Carman, 1990).

In general, continued embryo histodifferentiation beyond the globular stage and subsequent maturation requires the removal of growth regulators from the medium - or at least a 
decrease in growth regulator concentrations associated with induction and proliferation down to levels that enable proper embryo development (Merkle et al., 1995). Auxins suppress the development of the apical meristem, probably governed by the same mechanism involved in the establishment of apical dominance (Parrott et al., 1995).

The role of cytokinins during the histodifferentiation is more difficult to assess. Aung et al. (1982) observed a decrease in endogenous cytokinin levels during soybean zygotic embryo development. On the other hand, the inclusion of a cytokinin during the histodifferentiation phase can compensate for auxin-induced detrimental effects on meristem development. Globular-stage soybean somatic embryos, when exposed to a cytokinin, decrease the development rates while the apical meristem elongates so as to form multiple shoots (Wright et al., 1991).

Due to the fact that traditional embryogenesis protocols have typically used the same medium for histodifferentiation and the subsequent maturation phases, it is difficult to review the literature and determine if a given treatment affects the histodifferentiation stage or the maturation stage (Merkle et al., 1995).

Following histodifferentiation, the period of embryo development in which cell expansion and reserve deposition occur is considered the maturation phase (Fig. 1 B3) (Bewley et al., 1985). The time required for somatic embryos to achieve physiological maturity is speciesspecific, mirroring the maturation period of zygotic embryos in planta (Parrott et al., 1995). Analyses of reserve accumulations in developing somatic embryos have revealed both similarities and differences in comparison to zygotic embryos. These differences may primarily be attributed to the in vitro maturation conditions used. Many reports on somatic embryos reserve accumulations have not been carried out with optimal maturation protocols. Hence, manipulation of culture conditions to prolong and improve embryo maturation, and to prevent precocious germination, will probably add to the similarities observed between zygotic and somatic embryos (Merkle et al., 1995).

Currently, a trend is observed in the specification of numerous protocols towards providing various growth regulators in the medium during embryo maturation. Yet, there is ample information suggesting that neither exogenous auxin nor cytokinin is actually required for normal embryo maturation, as evidenced by the normal development of soybean zygotic (Hsu \& Obendorf, 1982) or somatic embryos (Parrott et al., 1988) in media devoid of any growth regulators. Indeed, poorly developed meristem or swollen hypocotyls may be an undesired outcome of the application of exogenous auxins and cytokinins, respectively. Consequently, a treatment that binds and removes auxin, by adding activated charcoal to the maturation medium (Ebert \& Taylor, 1990), for instance, may improve embryo development and enhance germination (Buchheim et al., 1989). Differently from auxins and cytokinins, abscisic acid (ABA) may be necessary during embryogenesis to initiate the synthesis of storage proteins and proteins involved in desiccation tolerance (Galau et al., 1990).

\subsection{Embryo germination and conversion into plants}

Embryos removed from maturation conditions for further development often display poor or aberrant subsequent germination, growth and vigor (Parrott et al., 1988). These observations suggest that further post-maturation treatments are required. One of the 
fundamental aspects of zygotic embryo development not normally encountered during somatic embryo development is desiccation (Fig. 1 B4), which leads to embryo quiescence. It has been proposed that desiccation is required for the correct transition from an embryo maturation program to a germination program (Kermode, 1990). The desiccation period has been linked with the synthesis of proteins associated with the ability to germinate (Rosenberg \& Rinne, 1986, 1988). Partial desiccation has been shown to enhance conversion of soybean somatic embryos (Hammatt \& Davey, 1987; Parrott et al., 1988; Buchheim et al., 1989).

While most studies report the development of roots and the germination of somatic embryos, little distinction is made between germination and conversion. According to Ranch et al. (1985), soybean germination refers to both root and shoot development in an embryo with intact hypocotyl (Fig. 1 B5). Walker \& Parrott (2001) described soybean apparent conversion as the development of expanded trifoliolates and branched roots under in vitro conditions (Fig. 1 B6). However, according to the authors, the definition of actual conversion refers to survival following transfer to soil.

While germination capacity may be affected by several culture medium components or environmental manipulations, one aspect that cannot be manipulated so readily is the genetic background of the embryo (Merkle et al., 1995). Studies with soybean plants indicated that germination/conversion capacity is also greatly influenced by genotype (Komatsuda \& Ohyama, 1988; Bailey et al., 1993; Santos et al., 1997; Droste et al., 2001, 2010).

\section{Genotype-dependent response and screening of highly responsive cultivars}

The more closely the pattern of somatic embryo gene expression matches that of zygotic embryos, the greater the chance of obtaining highly efficient regeneration systems. Such normalization of gene expression patterns will be achieved through the optimization of media and culture protocols for each individual stage of embryo development. According to Meurer et al. (2001), there are two ways to optimize soybean regeneration via embryogenic cultures. The first is screening a large number of new cultivars in order to identify those with embryogenic potential. Since SE is a heritable trait (Parrott et al., 1989), the potential for embryogenesis can be also improved through conventional crossing between nonresponsive cultivars and highly competent cultivars (Kita et al., 2007). An alternative and additive approach is to optimize embryogenesis protocols for improve results of an interesting cultivar.

Several studies have revealed the differences among soybean genotypes in their capacity to respond to the different steps of somatic embryogenesis (Bailey et al., 1993; Santos et al., 1997; Simmonds \& Donaldson, 2000; Droste et al., 2001; Meurer et al., 2001; Tomlin et al., 2002; Hiraga et al., 2007; Yang et al., 2009; Droste et al., 2010). The efficiencies were shown to be different among cultivars at each SE phase: induction, proliferation, histodifferentiation/maturation, germination and conversion (Bailey et al., 1993; Santos et al., 1997). As each phase must be under independent genetic control, the best cultivar performance in one stage not necessarily is the best in another one. In this context, Bailey et al. (1993a) reported that PI 417138 was among the least inducible genotypes studied, though it did have the highest germination and conversion capacity. In the same way, IAS- 5 cultivar 
had the lowest embryo yield but the highest conversion capacity (Santos et al., 1997). Tomlin et al. (2002) and Hiraga et al. (2007) suggested that differences in somatic embryo induction efficiency among soybean cultivars are likely to be attributed to differences in endogenous auxin levels or in the auxin sensitivity.

One of the major challenges in soybean is to identify genotypes highly responsive to SE induction, embryo proliferation and conversion into plants. A direct comparison among previous reports is difficult because each research group has adopted different protocols for SE and evaluation methods. In some studies only the first phases such as induction and/or proliferation were analyzed, while in other studies genotypes were screened upon plant regeneration.

Simmonds \& Donaldson (2002) screened 18 of 20 short-season soybean genotypes in Canada for proliferative embryogenic capacity. Only five genotypes produced embryogenic cultures which were proliferative for at least six months. Nine soybean cultivars representing different US growing regions were evaluated at each of three locations using uniform embryogenic induction and proliferation protocols. Several cultivars were identified as uniformly embryogenic at the primary induction phase at all locations, among which Jack was the best (Meurer et al., 2001).

Twenty-six genotypes including soybean wild relatives and Japanese cultivars were screened for differences of competence in both somatic embryogenesis and subsequent shoot formation. All genotypes were able to induce somatic embryos but with wide variation. Glycine gracilis, G. gracilis T34, Masshokutou (kou 502) and Masshokutou (kou 503) varieties presented high competence of germination from somatic embryos (Komatsuda \& Ohyama, 1988). Hiraga et al. (2007) examined the capacity for plant regeneration through somatic embryogenesis in Japanese soybean cultivars. Induction of somatic embryos from immature cotyledons, embryo proliferation in liquid medium and differentiation into cotyledon-stage embryos were evaluated. Yuuzuru and Yumeyutaka cultivars were found to have high potentials of plant regeneration through SE, being superior or comparable to North American cultivar Jack.

From a preliminary experiment using 98 Chinese soybean genotypes, 12 varieties were selected for further study in order to enhance the efficiency of somatic embryogenesis and plant regeneration. Significant differences in somatic embryogenesis were found among genotypes. N25281, N25263, and N06499 varieties were shown to have the highest somatic embryogenic capacities. The greatest average number of plantlets regenerated per explant was observed in N25281 (Yang et al., 2009).

Regarding Brazilian genotypes, Bonacin et al. (2000) demonstrated the influence of genotype influence in somatic embryogenic capability of five cultivars, of which BR-16, FT-Cometa and IAS-5 were the most embryogenic ones. That study only assessed somatic embryo induction stage. Other studies also reported the high capacity of IAS-5 to produce somatic embryos (Santos et al., 1997; Di Mauro et al., 2000; Droste et al., 2001). More recently, Droste et al. (2010) identified Brazilian soybean genotypes with potential to respond to in vitro culture stimuli for somatic embryo induction, embryo proliferation and plant regeneration. Somatic embryos were induced in all eight tested genotypes, but differences were observed at each stage. IAS-5 and BRSMG 68 Vencedora had high embryo induction frequencies, repetitive embryogenic proliferation, low precocious embryo germination, better embryo 
differentiation and plant regeneration. Thus, this work identified BRSMG 68 Vencedora and confirmed IAS-5 as genotypes with high potential for somatic embryogenesis and plant regeneration.

\section{Optimization of soybean somatic embryogenesis protocol}

Although somatic embryogenesis was described long ago and may be considered a routine procedure for other plant species, the first record of the event in soybean was made by Beversdorf \& Bingham (1977), when no more than a few embryos were produced. It was only in 1983 that Christianson et al. (1983) regenerated, for the first time, soybean plants via SE. Subsequently, several papers have reported the development of somatic embryos from cotyledons of immature embryos. But until today the measured frequencies at which these embryos convert into plants are significantly lower than that expected (Parrott et al., 1988; Meurer et al., 2001; Walker \& Parrott, 2001; Droste et al., 2001, 2010). Therefore, efforts have been directed towards developing and refining protocols for initiation, proliferation, and histodifferentiation/maturation of soybean somatic embryogenesis.

\subsection{Induction and proliferation of somatic embryos}

Most protocols described in the early studies failed to promote the satisfactory induction of somatic embryos. This limitation was overcome when embryos were induced from immature soybean cotyledons by placing the explant on high levels of 2,4-D (40 mg/l) (Finer, 1988). Comparing the capacity to induce soybean SE, the mean number of embryos produced on 2,4-D was significantly higher than that produced in the presence of NAA (Hoffmann et al., 2004). It is noteworthy to mention that the type of auxin used in the medium also influences culture morphology. Somatic embryos induced on 2,4-D are friable, translucent, yellowish-green in color, and globular to torpedo in shape. Somatic embryos induced on NAA are compact, opaque, pale-green in color, with an advanced morphology, forming cotyledon-like structures (Lazzeri et al., 1987; Hoffmann et al., 2004). Furthermore, Lazzeri et al. (1987) described that somatic embryos initiated on NAA had more normal embryo morphology.

The synergistic effect of $\mathrm{pH}$, solidifying agent, 2,4-D concentration, explants orientation and wounding have also been reported to improve efficiency of somatic embryo induction (Santarém et al., 1997). Embryo initiation was higher when explants were cultured with the abaxial side facing the induction medium containing high concentration of 2,4-D, $\mathrm{pH}$ adjusted to 7.0 and solidified with Gelrite ${ }^{\mathrm{TM}}$. Effect of $\mathrm{pH}$ was not observed or was slighter when somatic embryos were induced in the presence of other growth regulators (Lazzeri et al., 1987; Komatsuda \& Ko, 1990; Hoffman et al., 2004; Bonacin et al., 2000). It has been suggested that the effect of $\mathrm{pH}$ on somatic embryo initiation may be related to auxin uptake into cultured explants, and that a $\mathrm{pH}$ of 7.0 may facilitate slower and more gradual uptake of 2,4-D at relatively high level. Wounding treatment did not increase the number of embryos, although in wounded explants somatic embryos were induced earlier than in nonwounded counterparts (Santarém et al., 1997). In addition, efficiency on SE induction was highest when in a medium containing 2-3\% sucrose. Cultures initiated on lower sucrose concentrations tended to produce higher amount of friable embryos, while increased concentrations of this sugar impaired embryo induction (Lippmann \& Lippmann, 1984; Lazzeri et al., 1987, 1988; Hoffmann et al., 2004). 
After induced, the early-staged somatic embryos can be maintained and proliferated by subculturing the tissue on either semi-solid medium (Finer, 1988) or liquid suspension culture medium (Finer \& Nagasawa, 1988). As liquid medium allows greater contact of plant tissue with medium components, proliferation in liquid is usually more efficient than on a semi-solid medium (Samoylov et al., 1998a). On the other hand, soybean embryogenic suspension cultures can be very difficult to establish and maintain (Santarém et al., 1999). Although maintenance of soybean embryogenic cultures in liquid medium was facilitated by the development of FN medium (Finer \& Nagasawa, 1988), its efficiency remains low. Changes in individual medium components, such as carbohydrate type and concentration, total nitrogen, ammonium, nitrate, and other macronutrients, improved proliferation of soybean suspension cultures in liquid medium and resulted in the development of an optimized medium, referred to as FN Lite (Samoylov et al., 1998a).

Somatic embryos incubated in a medium containing NAA do not proliferate so well as those produced on a medium containing 2,4-D (Liu et al., 1992). As discussed above, somatic embryos initiated on NAA are more advanced in embryo morphology than those induced on 2,4-D. As a consequence, they are also not suitable for use in establishing repetitive cultures (Lazzeri et al., 1987; Hoffmann et al., 2004). Embryogenic cultures induced from immature cotyledons on a medium containing $40 \mathrm{mg} / 1$ required lower levels of 2,4-D for efficient proliferation (Bailey et al., 1993; Santarém \& Finer, 1999). Twenty mg/1 2,4-D are necessary to efficiently maintain repetitive embryogenesis on semi-solid medium (Santarém \& Finer, 1999), while $5 \mathrm{mg} / 1$ 2,4-D are sufficient on liquid suspension culture medium (Samoylov et al., 1998a). Furthermore, in contrast to the effect of $\mathrm{pH}$ on embryo initiation, cultures maintained on semisolid medium at $\mathrm{pH} 5.8$ or 7.0 showed no difference in proliferation rates, suggesting that once embryogenesis has been induced, the tissue does not necessary have to be maintained under the same conditions (Santarém et al., 1997).

\subsection{Histodifferentiation/maturation of somatic embryos and recovery of plants}

Even after three decades of intense research, soybean regeneration via somatic embryogenesis remains low if compared to other crops. Developmental limitations in somatic embryos are usually related to inadequate culture media composition (Merkle et al., 1994). So, efforts to better mimic the developmental environment of zygotic embryos were made to further improve SE. Deficiency in maturation stage has been identified as the main obstacle to somatic embryo conversion into plant. Somatic and zygotic embryos have been shown to diverge in sugars, protein, and total lipid accumulation, indicating that the somatic embryos did not develop properly and, as consequence, bring about difficulties for plant regeneration (Chanprame et al., 1998). In addition to embryo nutrition, appropriate sugar accumulation has been shown to be involved in soybean seed desiccation tolerance (Blackman et al., 1992).

Histodifferentiation and maturation of soybean somatic embryos has been basically achieved through the use of two protocols. The first one is a two-step process, whereby embryos are first histodifferentiated on MSM6AC medium (Bailey et al., 1993), which consists of solidified MS basal salts supplemented with $6 \%$ maltose and $0.5 \%$ activated charcoal. After 30 days, embryos are transferred to the same medium, but without charcoal, in order to allow growth and maturation to proceed. The second protocol is based on a liquid medium termed FNLS3, which consists of basal Finer \& Nagasawa "Lite" (FNL) salts 
supplemented with 3\% sucrose (Samoylov et al., 1998b). The main advantage of the liquid FNLS3 medium over the semi-solid MSM6AC/MSM6 medium is its ability to produce larger numbers of mature somatic embryos in a short period of time. On the other hand, liquid based protocols require greater care during handling.

Successful plant recovery has been reported using both protocols, though numerous studies suggested modifications to these basic media in order to optimize histodifferentiation and maturation of soybean somatic embryos, with the final goal of obtaining higher conversion rates. The main adaptations were: the type and concentration of carbon source, addition of osmotic agents, growth regulator agents and/or amino acids, type of basal salts, as well as the medium supplementation with activated charcoal (Tables 1 and 2). Modifications in other culture media are not considered in the present review.

\subsubsection{Carbon source and osmotic agents}

Carbon source is critical for embryo nutritional health and improves somatic embryo maturation. Carbohydrates are commonly used as carbon sources for in vitro development of tissues, and maltose and sucrose have been usually added to soybean tissue culture media in an optimal concentration range of 3\% to 6\% (Samoylov et al., 1998b; Körbes \& Droste, 2005; Schmidt et al., 2005). Carbon source type and concentration required for histodifferentiation/maturation appear to differ between solid and liquid media.

The effect of carbohydrates on embryo histodifferentiation and maturation on liquid medium was analyzed by Samoylov et al. (1998b). FNL medium supplemented with 3\% sucrose (FNL0S3) or 3\% maltose (FNLOM3) were compared. Data indicated that sucrose promotes embryo growth and significantly increases the number of cotyledon-stage embryos recovered during histodifferentiation and maturation. However, the percentages of plants recovered from embryos differentiated and matured in FNL0S3 was lower than those grown in FNL0M3 (Samoylov et al., 1998b). This limitation was partially solved by adding $3 \%$ sorbitol to the medium, which resulted in an increment in germination and conversion frequencies (Walker \& Parrott, 2001). The modified medium was named FNLS3S3 medium. It was suggested that sorbitol acts as an osmotic agent and/or promotes accumulation of triglycerides in somatic embryos. After addition of sorbitol, the effects of using $3 \%$ sucrose (FNLOS3S3) or 3\% maltose (FNL0M3S3) were compared again (Schmidt et al., 2005). Conversion rate of embryos differentiated on maltose was higher when compared to those obtained in sucrose. However, sucrose was considered the most appropriate carbon source, since its use in liquid maturation media resulted in a higher number of larger embryos, which required less time to reach physiological maturity.

The media that have been used in the two-step histodifferentiation/maturation process (MSM6AC/MSM6) contain 6\% maltose (Bailey et al., 1993). Körbes \& Droste (2005) compared conversion frequencies when $6 \%$ maltose was replaced by $3 \%$ maltose (MSM3) or $6 \%$ sucrose (MSS6). Results showed that maturation in MSS6 medium leads to an increment in rates of histodifferentiated embryos with normal morphology, as well as in plant recovery.

The quality of somatic embryos can be positively influenced by a low osmotic potential in maturation medium (Walker \& Parrott, 2001; Körbes \& Droste, 2005). Carbohydrates can act as an osmotic agent (Li et al., 1998). Since molecular weights of maltose and sucrose are very 
similar, no significant effect on the osmotic potential of the medium could be expected (Schmidt et al., 2005). Nevertheless, differences observed in embryos matured in media supplemented with maltose or sucrose have been related to these compounds' osmotic potentials (Samoylov et al., 1998b; Körbes \& Droste, 2005). Influence of other osmotic agents (sorbitol, mannitol and polyethylene glycol) has also been tested in soybean somatic embryogenesis (Walker \& Parrott, 2001; Körbes \& Droste, 2005; Schmidt et al., 2005), but positive effects were only reported for sorbitol (Walker \& Parrott, 2001), as described above.

\subsubsection{Amino acids}

The nitrogen source is also a critical component for proper embryo maturation. With a view to soybean embryo proliferation, $1 \mathrm{~g} / 1$ asparagine was included in the formulation of the original FN liquid medium (Finer \& Nagasawa, 1988), and it was also used in the FN Lite proliferation medium (Samoylov et al., 1998a) and FNL histodifferentiation/maturation medium (Samoylov et al., 1998b). On the other hand, culture media supplemented with glutamine were shown to be beneficial to zygotic soybean embryos (Thompson et al., 1977), by increasing embryo size (Lippmann \& Lippmann, 1993; Dyer et al., 1987), and inducing storage oil and protein synthesis (Saravitz \& Raper, 1995). Schmidt et al. (2005) compared the effect of FNLS3S3 supplemented with asparagine or glutamine on embryo histodifferentiation/maturation. The results showed that cotyledonary-stage embryos obtained on $30 \mathrm{mM}$ filter-sterilized glutamine were larger and exhibited an overall higher quality. The modified medium was named FNLS3S3G30 medium.

Methionine supplementation has also been reported to be helpful for growth stimulation (Coker et al., 1987). Thus, addition of $1 \mathrm{mM}$ methionine to FNL0S3S3 medium was tested and a clear positive effect on soybean somatic embryo histodifferentiation and maturation, manifested mainly by conversion percentages, was demonstrated (Schmidt et al., 2005). Again, this medium was renamed FNLS3S3G30M1 medium.

Improvements in the efficiency of solid MSM6 histodifferentiation/maturation medium were also obtained by using the ingredients from the optimized FNLS3S3G30M1 liquid medium recipe, specifically glutamine and methionine (Schmidt et al., 2005).

\subsubsection{Basal salts}

A comparison of embryo development showed that embryos differentiated into yellowgreen cotyledon-stage faster when cultured on FNLS3 than when maintained on MSM3 liquid media (Samoylov et al., 1998b). On the other hand, the number of histodifferentiated embryos and the frequency of germinated embryos recovered from MSM3 were higher than those obtained on FNLS3. Further studies showed that germination rates were increased when embryos histodifferentiated on FNLS3 supplemented with sorbitol, glutamine and methionine (Walker \& Parrott, 2001; Schmidt et al., 2005).

\subsubsection{Abscisic acid}

Abscisic acid (ABA) is a growth regulator involved in plant development, especially during embryo development and maturation and in response to abiotic stresses. In seeds, ABA induces storage protein synthesis and affects dormancy induction and maintenance (Rock \& Quatrano, 1995). ABA prevents precocious seed germination and is thought to play a major 


\begin{tabular}{|c|c|c|c|c|c|c|}
\hline \multirow{2}{*}{ Reference } & \multirow{2}{*}{$\begin{array}{c}\text { Main } \\
\text { modification }\end{array}$} & \multicolumn{4}{|c|}{ Culture tissue stage } & \multirow[b]{2}{*}{ Beneficial effects } \\
\hline & & Proliferation & $\begin{array}{l}\text { Histodiffe- } \\
\text { rentiation }\end{array}$ & Maturation & $\begin{array}{l}\text { Regeneration } \\
\text { / conversion }\end{array}$ & \\
\hline $\begin{array}{c}\text { Tian \& } \\
\text { Brown, } \\
2000\end{array}$ & $\begin{array}{c}\text { Abscisic } \\
\text { acid (ABA) } \\
\text { addition }\end{array}$ & $\begin{array}{c}\mathrm{FN}+ \\
50 \mu \mathrm{M} \mathrm{ABA}\end{array}$ & MSM6AC & MSM6AC & MSO & $\begin{array}{l}\text { promote embryo } \\
\text { growth } \\
\text { - } \text { increase } \\
\text { histodifferentiation of } \\
\text { embryo with normal } \\
\text { morphology } \\
\text { - improve embryo } \\
\text { viability } \\
\text { - } \text { enhance embryo } \\
\text { germination }\end{array}$ \\
\hline $\begin{array}{l}\text { Weber et. } \\
\text { al., } 2007\end{array}$ & $\begin{array}{c}\mathrm{ABA} \\
\text { addition }\end{array}$ & $\begin{array}{l}\mathrm{D} 20+50 \\
\mu \mathrm{M} \text { ABA }\end{array}$ & $\begin{array}{c}\text { MSM6 + } \\
50 \mu \mathrm{M} \\
\mathrm{ABA}\end{array}$ & MSM6 & MSO & $\begin{array}{l}\text { - increase embryo } \\
\text { conversion into plants }\end{array}$ \\
\hline $\begin{array}{c}\text { Körbes \& } \\
\text { Droste, } \\
2005\end{array}$ & $\begin{array}{c}\text { Maltose } \\
\text { replacement } \\
\text { with sucrose }\end{array}$ & D20 & MSS6 & MSS6 & MSO & $\begin{array}{l}\text { - increase } \\
\text { histodifferentiation of } \\
\text { embryo with normal } \\
\text { morphology } \\
\text { - increase embryo } \\
\text { conversion into plants }\end{array}$ \\
\hline $\begin{array}{l}\text { Schmidt } \\
\text { et al., } \\
2005\end{array}$ & $\begin{array}{l}\text { Glutamine } \\
\text { and } \\
\text { methionine } \\
\text { addition }\end{array}$ & & $\begin{array}{c}\text { MSM6 + } \\
30 \mathrm{mM} \\
\text { glutamine } \\
\text { + } 1 \mathrm{mM} \\
\text { Methionine }\end{array}$ & & & $\begin{array}{l}\text { - increase the } \\
\text { number of } \\
\text { histodifferentiated } \\
\text { embryos } \\
\text { - } \text { increase embryo } \\
\text { conversion into plants }\end{array}$ \\
\hline $\begin{array}{l}\text { Droste et } \\
\text { al., } 2010\end{array}$ & $\begin{array}{l}\text { Activated } \\
\text { charcoal } \\
\text { (AC) } \\
\text { addition }\end{array}$ & D20 & $\begin{array}{l}\text { MSS6 + } \\
0.5 \% \text { AC }\end{array}$ & MSS6 & MSO & $\begin{array}{l}\text { - increase the } \\
\text { number of } \\
\text { histodifferentiated } \\
\text { embryos }\end{array}$ \\
\hline
\end{tabular}

Table 1. Optimization of MSM6AC medium. D20 - MS salts (Murashige \& Skoog, 1962), B5 vitamins (Gamborg et al., 1968), 3\% sucrose, $20 \mathrm{mg} / 1$ 2,4-D, and $0.2 \%$ Gelrite or $0.3 \%$ Phytagel (pH 5.8) (Wright et al., 1991). MSM6AC - MS salts, B5 vitamins, $6 \%$ maltose, $0.5 \%$ activated charcoal and 0.25\% Gelrite or 0.3\% Phytagel (pH 5.8) (Bailey et al., 1993). MSM6 MS salts, B5 vitamins, $6 \%$ maltose and $0.25 \%$ Gelrite or $0.3 \%$ Phytagel (pH 5.8) (Finer \& McMullen, 1991). MSS6 - MS salts, B5 vitamins, 6\% sucrose, 0.3\% Phytagel (pH 5.8) (Körbes \& Droste, 2005). MSO - MS basal salts, B5 vitamins, 3\% sucrose, and $0.2 \%$ Gelrite, at pH 5.8

role in the sequence of events leading to desiccation tolerance (Hoekstra et al., 2001). ABA supplementation in culture media was shown to affect somatic embryogenesis of a variety of plants. Having this in mind, it was suggested that medium containing low ABA concentrations $(0.38$ or $1 \mu \mathrm{M})$ helps soybean immature somatic embryos to achieve maturity and further develop apical meristems (Ranch et al., 1885; Lazzeri et al., 1987). However, independently of the protocol used, no significant effect was observed when ABA was added to histodifferentiation or maturation medium (Tian \& Brown, 2000; Schmidt et al., 
2005; Weber et al., 2007). Tian \& Brown (2000) investigated the effect of ABA addition to culture media in different embryogenic stages: proliferation, histodifferentiation and maturation. The positive effects of ABA were observed only when embryos at a globular stage (proliferation) were treated prior to histodifferentiation induction. Addition of $50 \mu \mathrm{M}$ ABA promoted growth of histodifferentiated embryos, increased proportion of morphological normal histodifferentiated embryos, improved embryo viability after desiccation and increased germination frequency. In agreement, Weber et al. (2007) demonstrated that presence of ABA during proliferation or during both proliferation and maturation stages increased percentage of converted plants.

\begin{tabular}{|c|c|c|c|c|c|}
\hline \multirow[b]{2}{*}{ Reference } & \multirow[b]{2}{*}{$\begin{array}{c}\text { Main } \\
\text { modification }\end{array}$} & \multicolumn{3}{|c|}{ Culture tissue stage } & \multirow[b]{2}{*}{ Beneficial effects } \\
\hline & & Proliferation & $\begin{array}{l}\text { Histodifferen- } \\
\text { tiation/ } \\
\text { maturation }\end{array}$ & $\begin{array}{l}\text { Regeneration } \\
\text { / conversion }\end{array}$ & \\
\hline $\begin{array}{l}\text { Walker \& } \\
\text { Parrott, } 2001\end{array}$ & $\begin{array}{l}\text { Sorbitol } \\
\text { addition }\end{array}$ & $\begin{array}{l}\text { D20/ FN } \\
\text { Lite }\end{array}$ & $\begin{array}{l}\text { FNL0S3 + 1.5-3\% } \\
\text { sorbitol }\end{array}$ & MSO & $\begin{array}{l}\text { - } \text { reduce fresh weight of } \\
\text { mature embryos } \\
\text { - increase embryo } \\
\text { regeneration and } \\
\text { conversion into plants }\end{array}$ \\
\hline \multirow[t]{4}{*}{$\begin{array}{l}\text { Schmidt et } \\
\text { al., } 2005\end{array}$} & $\begin{array}{l}\text { Standard } \\
\text { medium }\end{array}$ & FN Lite & FNL0S3S3 & MSO & $\begin{array}{l}\text { - } \text { increase number of } \\
\text { matured embryos } \\
\text { - give rise to larger } \\
\text { embryos } \\
\text { - need shorter time to } \\
\text { reach physiological } \\
\text { maturity } \\
\text { - reduce embryo } \\
\text { conversion into plants }\end{array}$ \\
\hline & $\begin{array}{l}\text { Sucrose } \\
\text { replacement by } \\
\text { maltose }\end{array}$ & FN Lite & FNL0M3S3 & MSO & $\begin{array}{l}\text { reduce number of } \\
\text { matured embryos, } \\
\text { - give rise to smaller } \\
\text { embryos } \\
\text { - need longer time to } \\
\text { reach physiological } \\
\text { maturity } \\
\text { - increase embryo } \\
\text { conversion into plants }\end{array}$ \\
\hline & $\begin{array}{l}\text { Glutamine } \\
\text { addition }\end{array}$ & FN Lite & $\begin{array}{l}\text { FNL0S3S3 + } \\
30 \text { mM glutamine }\end{array}$ & MSO & $\begin{array}{l}\text { give rise to larger } \\
\text { embryos }\end{array}$ \\
\hline & $\begin{array}{l}\text { Methionine } \\
\text { addition }\end{array}$ & FN Lite & $\begin{array}{c}\text { FNL0S3S3G30 + } \\
1 \mathrm{mM} \\
\text { Methionine }\end{array}$ & MSO & $\begin{array}{l}\text { - increase embryo } \\
\text { conversion into plants }\end{array}$ \\
\hline
\end{tabular}

Table 2. Optimization of FNLS3 medium. FN Lite - FN Lite macro salts (Samoylov et al., 1998a), MS micro salts (Murashige \& Skoog, 1962), B5 vitamins (Gamborg et al., 1968), 6.7 mM L-asparagine, 1\% sucrose , $146.1 \mathrm{mM}$ mannitol and $0.5 \mathrm{mg} / 1$ 2,4-D, at pH 5.8 (Samoylov et al., 1998a). FNL0S3 - FN Lite macro salts, MS micro salts, B5 vitamins, $6.7 \mathrm{mM}$ Lasparagine and 3\% sucrose, at pH 5.8 (Samoylov et al., 1998b). MSO - MS basal salts, B5 vitamins, $1.5 \%$ sucrose, and $0.2 \%$ Gelrite, at $\mathrm{pH} 5.8$. 


\subsubsection{Activated charcoal}

Activated charcoal (AC) is a porous material composed of carbon. AC has a unique adsorption capacity and is often used in plant tissue culture to improve cell growth and development. Applicability of AC is credited mainly to its capacity as adsorbent of inhibitory substances in the culture medium (Thomas, 2008). As previously discussed (Induction and proliferation of somatic embryos section), high concentrations of 2,4-D are necessary to stimulate soybean somatic embryo induction and proliferation (Finer, 1988; Samoylov et al., 1998a; Santarem \& Finer, 1999). On the other hand, this growth regulator can lead to abnormal embryo histodifferentiation or development of apical meristem, especially in long-term cultures under exposure to 2,4-D. AC is presumably able to adsorb 2,4-D or other auxins released from developing tissues, promoting a more normal embryo morphology and increasing germination ability (Merkle et al., 1995).

AC was present in a medium originally described by Bailey et al. (1993) for embryo histodifferentiation/maturation, but it has not been applied in further studies (Samoylov et al., 1998b; Walker \& Parrott, 2001; Körbes \& Droste, 2005; Schmidt et al., 2005; Weber et. al., 2007). Recently, it has been observed that addition of activated charcoal and ABA to the first step histodifferentiation/maturation medium increased the number of histodifferentiated embryos (Droste et al., 2010). Since positive effects were not identified when ABA was added in histodifferentiation/maturation medium (Schmidt et al., 2005; Weber et. al., 2007) (discussed in the section about abscisic acid), the benefits described by Droste et al. (2010) must be related to AC supplementation.

It is important to stress that studies were carried out with different genotypes and that soybean response to in vitro culture conditions is genotype-dependent. Further studies, specially focusing on embryo histodifferentiation and maturation, are important and necessary to improve soybean embryogenesis of highly responsive cultivars.

After appropriate maturation, a desiccation stage is required. Conversion of partialdesiccated soybean somatic embryos was shown to proceed more vigorously than nondesiccated ones (Buchheim et al., 1989). The partial desiccation has been adopted by most research teams (Bailey et al., 1993; Samoylov et al., 1998b; Tian \& Brown, 2000; Walker \& Parrott, 2001; Droste et al., 2002, 2010; Körbes \& Droste, 2005; Schmidt et al., 2005; Yang et al., 2009; Wiebke-Strohm et al., 2011). Although there is a broad number of media available for histodifferentiation/maturation, MSO (MS basal salts, B5 vitamins, $3 \%$ sucrose, and $0.2 \%$ Gelrite $^{\mathrm{TM}}$, at pH 5.8) medium has been almost exclusively used for soybean somatic embryos germination/conversion stage (Finer \& McMullen, 1991; Bailey et al., 1993; Samoylov et al., 1998b; Tian \& Brown, 2000; Walker \& Parrott, 2001; Droste et al., 2002, 2010; Körbes \& Droste, 2005; Schmidt et al., 2005; Wiebke-Strohm et al., 2011).

\section{Genetic transformation of soybean somatic embryos via particle bombardment and bombardment/Agrobacterium integrated system}

Plant genetic transformation is described as the introduction of recombinant DNA in plant cells using genetic engineering methods. Transgenic plants represent a priceless tool for molecular, genetic, biochemical and physiological studies. Plant genetic transformation also offers a significant advancement for soybean breeding programs, in terms of allowing the production of novel and genetically diverse plant materials. 
Advancements in the use of plant transgenesis have been reported for a large number of species. Such progress entails the adoption of different protocols, which include the genetic transformation mediated by polyethyleneglycol (PEG) and liposomes (known under the heading of chemical methods), microinjection, electroporation and particle bombardment (called physical methods), as well as the use of viral and/or bacterial vectors, as in agroinfection and the Agrobacterium system (named biological methods).

Soybean transformation was first reported in 1988 by two independent groups using different methods (Hinchee et al., 1988; Christou et al., 1988). Even after more than two decades, the stable transformation of soybean cannot yet be considered as routine because it depends on the ability to bring together efficient transformation and regeneration techniques. Two methods have been successfuly used: particle bombardment (McCabe et al., 1988; Christou et al., 1989; Finer \& McMullen, 1991; Christou \& McCabe, 1992; Finer et al., 1992; Stewart et al., 1996; Aragão et al., 2000; Droste et al., 2002; Homrich et al., 2008; Wu et al., 2008; Li et al., 2009; Hernandez-Garcia et al., 2009; Xing et al., 2010; Viana et al., 2011) and Agrobacterium tumefaciens system (Parrott et al., 1989; Trick et al., 1997; Trick \& Finer, 1998; Aragão et al., 2000; Yan et al., 2000; Ko et al., 2003, 2004; Paz et al., 2006; Hong et al., 2007; Miklos et al., 2007; Liu et al., 2008; Wang \& Xu, 2008; Wiebke-Strohm et al., 2011).

Regardless of the method used, the unicellular origin of soybean secondary somatic embryos makes them a useful target tissue for transformation, allowing the production of fully transformed plants. The first target used for transformation was primary somatic embryos, but chimerical plants were obtained (Parrott et al., 1989) due to the multicellular nature of primary embryos (Sato et al., 1993). Finer (1988) showed that the secondary somatic embryos proliferated directly from the apical or terminal portions of the older primary somatic embryos. Sato et al. (1993) proved that somatic embryo proliferation occurred from single epidermal cells of existing somatic embryos. Using proliferative embryos as target tissue many studies succeed in regenerating completely transformed plants (Finer \& McMullen, 1991; Finer et al., 1992; Stewart et al., 1996; Trick et al., 1997; Trick \& Finer, 1998; Droste et al., 2002; Homrich et al., 2008; Schmidt et al., 2008; Wu et al., 2008; Li et al., 2009; Hernandez-Garcia et al., 2009; Xing et al., 2010; Wiebke-Strohm et al., 2011).

\subsection{Agrobacterium system}

Agrobacterium tumefaciens is a soil-borne Gram-negative phytopatogenic bacterium that naturally infects different plants causing the crown gall disease (DeCleene \& DeLay, 1976). The origin of these sicknesses is interkingdom horizontal gene transfer. When virulent strains of Agrobacterium infect plant cells, they transfer one or more segments of DNA (transferred DNA or T-DNA) from Ti (Tumor inducing) plasmids into host plant cells (recently reviewed by Gelvin, 2010 a,b; Pitzschke \& Hirt, 2010). In recent decades, disarmed (non-tumorigenic) A. tumefaciens strains have also provided a means to produce genetically modified plants. In order to obtain engineered binary vectors derived from Ti plasmids, oncogenes present in T-DNA region are replaced by any foreign DNA of interest (Gelvin, 2010b).

The advantages of Agrobacterium-mediated gene transfer include the possibility of transferring relatively large segments of DNA, lower number of transgene copies integration into plant genomes, rare transgene rearrangement, lower frequency of genomic DNA interspersion and reduced abnormal transgene expression (Gelvin, 2003; Kohli et al., 
2003). Moreover, this system involves low operating cost and simplicity of transformation protocols. On the other hand, plants differ greatly in their susceptibility to Agrobacteriummediated transformation. These differences occur among species, cultivars or tissues (Droste et al., 1994; Gelvin, 2010b). In addition, in our laboratory this transformation system usually results in lower transformation rates, if compared to particle bombardment.

Agrobacterium-mediated transformation system is a growing trend in crop transformation programs (Somers et al., 2003). Soybean has long been considered recalcitrant to Agrobacterium (DeCleene \& DeLey, 1976), especially due to the low success rate in recovering transgenic plants. Studies with tumorigenic Agrobacterium strains (Pedersen et al., 1983; Droste et al., 1994; Mauro et al., 1995) and transient assays (Meurer et al., 1998; Droste et al., 2000) showed that soybean can be readily transformed by this bacterium. Currently, it is known that addition of acetosyringone during bacterial infection, combination of appropriate Agrobacterium strain and soybean cultivar, as well as development of super virulent bacterium strain and suitable plasmids increase efficiency of soybean transformation (Somers et al., 2003; Ko et al., 2003, 2004; Wiebke-Strohm et al., 2011).

Transgenic plants regenerated via somatic embryogenesis were obtained using two different target tissues: immature zygotic cotyledons and secondary somatic embryos. In the first case, wounded immature zygotic cotyledons are co-cultivated with Agrobacterium suspension, after which embryogenic tissue formation is induced from the surface of these cotyledons. In the second case, proliferative secondary somatic embryos are first obtained and then submitted to transformation experiments.

Transformation of zygotic cotyledons by A. tumefaciens and subsequent regeneration of transformed soybean plants was first reported by Parrott et al. (1989). Plants were regenerated from primary somatic embryos and, due to embryo multi-cellular origin, plants were chimeric. As a consequence, transgenes were not present in the germ line and transmitted to the progeny. Still using zygotic cotyledons as target, a new approach was developed in which formation of secondary somatic embryos was allowed under continued selection system. The unicellular origin of secondary somatic embryos permitted recovery of complete, stable and fertile transgenic plants, whose progeny also displayed these characteristics (Yan et al., 2000; Ko et al., 2003).

Transformation of proliferative secondary somatic embryos via A. tumefaciens has proven to be challenging and only succeeded when combined to physical methods that generate an entry point to bacteria penetration. Instead of the conventional transformation system, two alternative methods have been proposed for this target tissue: the Sonication-Assisted Agrobacterium-mediated Transformation (SAAT) (Trick et al., 1997; Trick \& Finer, 1998), and the combined DNA-free particle bombardment and Agrobacterium system (bombardment/Agrobacterium integrated system) (Droste et al., 2000; Wiebke et al., 2006, Wiebke-Strohm et al., 2011). The difference between these methods lies in the technique used to induce tissue wounding: while the first one used sonication, the second relied upon bombardment. Although these methods proved to be feasible, both systems are timeconsuming, laborious, and depend on the availability of specific equipments for routine application.

It is important to stress that the success in soybean Agrobacterium-mediated transformation and regeneration via somatic embryogenesis depends on the availability of cultivars with superior response to in vitro culture stimuli and high susceptibility to this bacterium. So far, 
regeneration of transgenic plants was achieved using immature zygotic cotyledons of Jack, Williams and Dwight cultivars (Yan et al., 2000; Ko et al., 2003) or proliferative secondary somatic embryos of Chapman, Bragg, IAS5 \& BRMG 68 Vencedora cultivars (Trick et al., 1997; Trick \& Finer, 1998; Droste et al., 2000; Wiebke-Strohm et al., 2011).

\subsection{Particle bombardment}

Genetic transformation by particle bombardment (Sanford, 1988), also called particle or projectile acceleration, biolistics or biobalistics, consists of the introduction of DNA in intact cells and tissues by accelerated microprojectiles driven at high speeds. These projectiles are able to cross the wall and the membranes of the cell and of the nucleus, where DNA fragments are liberated (Trick \& Finer, 1997). In this organelle, exogenous DNA may then be integrated to chromosomal DNA through processes of illegitimate or homologous recombination that depends exclusively on cell components (Sanford, 1990; Kohli et al., 2003). Particle bombardment affords the introduction of DNA in plant cells by means of plasmids (Hadi et al., 1996; Homrich et al., 2008) or gene cassettes (Fu et al., 2000; Breitler et al., 2002). In this method, DNA is adhered to metal particles called microcarriers. The metals used in the process have to be inert, like gold or tungsten, so as to prevent particles from reacting with DNA or cell components (Christou et al., 1990). The DNA-particle complex is accelerated towards the target cells using different apparatuses based on diverse acceleration mechanisms.

Particle bombardment can be achieved through high or low helium pressure gene guns. So, penetration in the target tissue can be controlled very accurately, directing the majority of the particles carrying the DNA to a specific cell layer. This is an extremely important feature, because different explants may require different acceleration conditions for optimum particle penetration (Christou et al., 1990). As single epidermal cells are responsible for the initiation of secondary somatic embryos (Sato et al., 1993), a shallow penetration resulting from bombardment of low helium pressure ensures efficient transformation (Sato et al., 1993). Finer et al. (1992) developed a low helium pressure particle accelerator called Particle Inflow Gun (PIG).

The main advantage of particle bombardment lies in the possibility to transfer genes to any cell or tissue type independently of genotype and without having to consider the compatibility between host and bacterium, as required by the Agrobacterium system. On the other hand, using this technique, multiple DNA copies are introduced which may recombine or be fragmented (Hadi et al., 1996; Kohli et al., 2003).

Several studies about soybean transformation via particle bombardment using embryogenic tissues have been published (Finer \& McMullen, 1991; Finer et al., 1992; Stewart et al., 1996; Droste et al., 2002; Homrich et al., 2008; Schmidt et al., 2008; Wu et al., 2008; Li et al., 2009; Hernandez-Garcia et al., 2009; Xing et al., 2010).

\section{Conclusion}

Proliferative somatic embryos are one of the most suitable and convenient targets for soybean genetic transformation. However, after two decades, the stable transformation of somatic embryos cannot yet be considered as routine. The absence of a highly efficient regeneration procedure is the main limiting factor. Advances have been made in the 
identification of cultivars with high potential for embryogenesis, as well as in the optimization of media and culture protocols. Large efforts are being made to render more efficient soybean plant regeneration via somatic embryogenesis. By recognizing the critical factors, the protocols of each individual stage of the somatic embryogenic process can be improved to more closely simulate zygotic embryo development in planta.

\section{Acknowledgment}

Authors are grateful to Conselho Nacional de Desenvolvimento Científico e Tecnológico $\mathrm{CNPq}$, Brazil for the Postdoctoral Fellowships.

\section{References}

Aragão, F.J.L.; Sarokin, L.; Vianna, G.R. \& Rech, E.L. (2000). Selection of transgenic meristematic cells utilizing a herbicidal molecule results in the recovery of fertile transgenic soybean [Glycine $\max (\mathrm{L})$ Merrill] plants at a high frequency. Tag Theoretical and Applied Genetics, Vol.101, No.1-2, (2000), pp. 1-6, ISSN 0040-5752

Aung, L.H.; Buss, G.R.; Crosby, K.E. \& Brown, S.S. (1982). Changes in the hormonal levels of soybean fruit during ontogeny. Phyton, Vol.45, (1982), pp. 182-185, ISSN 0031-9457

Bailey, M.A.; Boerma, H.R. \& Parrott, W.A. (1993). Genotype effects on proliferative embryogenesis and plant regeneration of soybean. In Vitro Cellular and Developmental Biology-Plant, Vol.29, No.3, (July 1993) pp. 102-108, ISSN 1054-5476

Barwale, U.B.; Kerns, H.R. \& Widholm, J.M. (1986). Plant regeneration from callus cultures of several soybean genotypes via embryogenesis and organogenesis. Planta, Vol.167, No.4, (1986), pp. 473-481, ISSN 0032-0935

Beversdorf, W.D. \& Bingham, E.T. (1977). Degrees of differentiation obtained in tissue cultures of Glycine species. Crop Science, Vol.17, No.2, (1977), pp. 307-311, ISSN 0011-183X

Bingham, E.T; McCoy T.J. \& Walker K.A. (1988). Alfalfa tissue culture. In: Alfalfa and alfalfa improvement, A.A. Hanson, D.K. Barnes, R.R. Hill Jr, (Eds), 903-929, American Society of Agronomy, ASA-CSSA-SSSA, ISBN 0-89118-094-X, Madison WI

Blackman, S.A.; Obendorf, R.L. \& Leopold, A.C. (1992). Maturation proteins and sugars in desiccation tolerance of developing soybean seeds. Plant Physiology, Vol.100, No.1, (September 1992), pp. 225-230, ISSN 0032-0889

Bonacin, G.A.; DiMauro, A.O.; Oliveira, R.C. \& Perecin, D. (2000). Induction of somatic embryogenesis in soybean: physicochemical factors influencing the development of somatic embryos. Genetics and Molecular Biology, Vol.23, No.4, (December 2000), pp. 865-868, ISSN 1415-4757

Breitler, J.C.; Labeyrie, A.; Meynard, D.; Levavre, T. \& Guiderdoni, E. (2002). Efficient microprojectile bombardment-mediated transformation of rice using gene cassettes. Tag Theoretical and Applied Genetics, Vol.104, No.4, (2002), pp. 709-719, ISSN 00405752

Buchheim, J.A.; Colburn, S.M. \& Ranch, J.P. (1989). Maturation of soybean somatic embryos and the transition to plantlet grown. Plant Physiology, Vol.89, (1989), pp. 768-77, ISSN 0032-0889 
Carman, J.G. (1990). Embryogenic cells in plant tissue cultures: occurrence and behavior. In Vitro Cellular and Developmental Biology-Plant, Vol.26, (August 1990), pp. 743-756, ISSN 0883-8364

Chanprame, S.; Kuo, T.M. \& Widholm, A.M. (1998). Soluble carbohydrate content of soybean [Glycine max (L.) Merr.] somatic and zygotic embryos during development. In Vitro Cellular and Developmental Biology-Plant, Vol.34, (January-March 1998), pp. 64-68, ISSN 1054-5476

Christianson, M.L.; Warnick, D.A. \& Carlson, P.S. (1983). A morphogenetically competent soybean suspension culture. Science, Vol.222, No.4624 (November 1983), pp.632634, ISSN 0036-8075

Christou, P. \& McCabe, D.E. (1992). Prediction of germ-line transformation events in chimeric R0 transgenic soybean plantlets using tissue-specific expression patterns. The Plant Journal, Vol.2, No.3, (May 1992), pp. 283-290, ISSN 0960-7412.

Christou, P. \& Yang, N.S. (1989). Developmental aspects of soybean (Glycine max) somatic embryogenesis. Annals of Botany, Vol.64, No.2, (1989), pp. 225-234, ISSN 03057364

Christou, P.; McCabe, D.E. \& Swain, W.F. (1988). Stable transformation of soybean callus by DNA-coated gold particles. Plant Physiology, Vol.87, (1988), pp. 671-674, ISSN 00320889

Christou, P.; McCabe, D.E.; Martinell, B.J. \& Swain, W.F. (1990). Soybean genetic engeneering-commercial products of transgenic plants. Trends Biotechnology, Vol.18, (1990), pp. 145-151, ISSN 0167-7799

Christou, P.; Swain, W.F.; Yang, N.S. \& McCabe, D.E. (1989). Inheritance and expression of foreign genes in transgenic soybean plants. Proceedings of the National Academy of Sciences of the United States of America, Vol.88, (October 1989), pp. 7500-7504, ISSN 0027-8424

Coker, G.T.I.; Garbow, J.R. \& Schaefer, J. (1987). 15N and 13C NMR determination of methionine metabolism in developing soybean cotyledons. Plant Physiology, Vol.83, (1987), pp. 698-702, ISSN 0032-0889

DeCleene, M. \& DeLey, J. (1976). The host range of crown gall. Botanical Gazette, Vol.42, (1976), pp.389-466, ISSN 0006-8071

Dhanalakshmi, S. \& Lakshmanan, K.K. (1992). In vitro somatic embryogenesis and plant regeneration in Clitoria ternatea. Journal of Experimental Botany, Vol.43, No.2, (1992), pp. 213-219, ISSN 0022-0957

Di Mauro, A.O.; de Oliveira, R.C. \& de Oliveira, J.A. (2001). Capacidade embriogênica da cultivar IAS-5 de soja. Pesquisa Agropecuária Brasileira, Vol.36, No.11, (November 2001), pp. 1381-1385, ISSN 0100-204X

Dodeman, V.L.; Ducreux, G. \& Kreis, M. (1997). Zygotic embryogenesis versus somatic embryogenesis. Journal of Experimental Botany, Vol. 48, No.313, (August 1997), pp. 1493-1509, ISSN 0022-0957

Droste, A.; Bodanese-Zanettini, M.H.; Mundstock, E. \& Hu, C.Y. (1994). Susceptibility of Brazilian soybean cultivars to Agrobacterium tumefaciens. Brazilian Journal of Genetics, Vol.17, (1994), pp. 83-88, ISSN 0100-8455

Droste, A.; Pasquali, G. \& Bodanese-Zanettini, M.H. (2000). Integrated bombardment and Agrobacterium transformation system: an alternative method for soybean 
transformation. Plant Molecular Biology Reports, Vol.18, No.1, (2000), pp. 51-59, ISSN 0735-9640

Droste, A.; Pasquali, G. \& Bodanese-Zanettini, M.H. (2002). Transgenic fertile plants of soybean [Glycine max (L) Merrill] obtained from bombarded embryogenic tissue. Euphytica, Vol. 127, No.3, (2002), pp. 367-376, ISSN 0014-2336

Droste, A.; Silva, A.M.; Souza, I.F.; Wiebke-Strohm, B.; Bücker-Neto, L.; Bencke, M.; Sauner, M.V. \& Bodanese-Zanettini, M.H. (2010). Screening of Brazilian soybean genotypes with high potential for somatic embryogenesis and plant regeneration. Pesquisa Agropecuária Brasileira, Vol.45, No.7, (July 2010), pp.715-720, ISSN 0100-204X

Droste, A.; Leite, P.C.P.; Pasquali, G.; Mundstock, E.C. \& Bodanese-Zanettini, M.H. (2001). Regeneration of soybean via embryogenic suspension culture. Scientia Agricola, Vol.58, No.4, (October-Deyember 2001), pp.753-758, ISSN 0103-9016

Dyer, D.J.; Cotterman, C.D. \& Cotterman, J.C. (1987). Comparison of in situ and in vitro regulation of soybean seed growth and development. Plant Physiololgy, Vol.84, No.2, (Juny 1987), pp. 298-303, ISSN 0032-0889

Ebert, A. \& Taylor, H.F. (1990). Assessment of the changes of 2,4-dichlorophenoxyacetic acid concentrations in plant tissue culture media in the presence of activated charcoal. Plant Cell, Tissue and Organ Culture, Vol.20, No.3, (1990), pp. 165-172, ISSN 01676857

Fernando, J.A.; Vieira, M.L.C.; Geraldi, I.O. \& Appezzato-da-Gloria, B. (2002). Anatomical study of somatic embryogenesis in Glycine max (L.) Merrill. Brazilian Archives of Biology and Technology, Vol.45, No.3, (September 2002), pp. 277-286, ISSN 15168913

Finer, J. J. \& Nagasawa, A. (1988). Development of an embryogenic suspension culture of soybean (Glycine max Merrill). Plant Cell, Tissue and Organ Culture, Vol.15, (1988), pp. 125-136, ISSN 0167-6857

Finer, J.J. \& McMullen, M.D. (1991). Transformation of soybean via particle bombardment of embryogenic suspension culture tissue. In vitro Cellular and Developmental BiologyPlant, Vol.27, No.4, (October 1991), pp. 175-182, ISSN 1054-5476

Finer, J.J. (1988). Apical proliferation of embryogenic tissue of soybean (Glycine max (L.) Merrill). Plant Cell Reports, Vol.7, No.4, (1988), pp. 238-241, ISSN 0721-7714

Finer, J.J.; Vain, P.; Jones, M.W. \& McMullen, M.D. (1992). Development of the particle inflow gun for DNA delivery to plant cells. Plant Cell Reports, Vol.11, No.7, (1992), pp.323-328, ISSN 0721-7714

Fu, X.; Due, L.T.; Fontana, S.; Bong, B.B.; Tinjuangjun, P.; Sudhakar, D.; Twyamn, R. M.; Christou, P. \& Kohli, A. (2000). Linear transgene constructs lacking vector backbone sequences generate low-copy-number transgenic plants with simple integration patterns. Transgenic Research, Vol.9, (2000), pp. 11-19, ISSN 09628819

Galau, G.A.; Jakobsen, K.S. \& Hughes, D.W. (1991). The controls of late dicot embryogenesis and early germination. Physiologia Plantarum, vol.81, No.2, (February 1991), pp. 280288, ISSN 0031-9317

Gamborg, O.L.; Miller, R.A. \& Ojima, K. (1968). Nutrient requirements of suspension cultures of soybean root cells. Experimental Cell Research, Vol.50, No.1, (April 1968), pp.151-158, ISSN 0014-4827 
Gelvin, S.B. (2003). Agrobacterium and plant transformation: the biology behind the "genejockeying" tool. Microbiology and Molecular Biology Reviews, Vol.67, No.1, (March 2003), pp. 16-37, ISSN 1092-2172

Gelvin, S.B. (2010a). Finding a way to the nucleus. Current Opinion in Microbiology, Vol.13, No.1, (February 2010), pp. 53-58, ISSN 1369-5274

Gelvin, S.B. (2010b). Plant proteins involved in Agrobacterium-mediated genetic transformation. Annual Review Phytopathology, Vol.48, (March 2010), pp. 45-68, ISSN 0066-4286

Gharyal, P.K. \& Maheswari, S.C. (1983). In vitro differentiation of somatic embryos in a leguminous tree, Albizia lebbeck L. Naturwissenschaften, Vol.68, (1983), pp. 379-380, ISSN 0028-1042

Ghazi T.D.; Cheema H.V. \& Nabors M.W. (1986). Somatic embryogenesis and plant regeneration from embryonic callus of soybean [Glycine max (L.) Merr.]. Plant Physiology, Vol.77, (1986), p. 863-868, ISSN 0032-0889

Hadi, M.Z.; McMullen, M.D. \& Finer, J.J. (1996). Transformation of 12 different plasmids into soybean via particle bombardment. Plant Cell Reports, Vol.15, No., (1996), pp. 500-505, ISSN 0721-7714

Hammatt, N. \& Davey, M.R. (1987). Somatic embryogenesis and plant regeneration from cultured zygotic embryos of soybean (Glycine max L. Merr.). Journal of Plant Physiology, Vol.128, No.3, (1987), pp. 219-226, ISSN 0176-1617

Hartweck, L.M.; Lazzeri, P.A.; Cui, D.; Collins, G.B. \& Williams, E.G. (1988). Auxinorientation effects on somatic embryogenesis from immature soybean cotyledons. In Vitro Cellular and Developmental Biology-Plant, vol.24, No.8, (August 1988), pp. 821-828, ISSN 1054-5476

Hernandez-Garcia, C.M.; Martinelli, A.P.; Bouchard, R.A. \& Finer, J.J. (2009). A soybean (Glycine max) polyubiquitin promoter gives strong constitutive expression in transgenic soybean. Plant Cell Reports, Vol.28, No.5, (2009), pp. 837-849, ISSN 07217714

Hinchee, M.A.; Connor-Ward, D.V.; Newell, C.A.; McDonell, R.E.; Sato, S.J.; Gasser, C.S.; Fishhoff, D.A.; Re, D.B.; Fraley, R.T. \& Horsch, R.B. (1988). Production of transgenic soybean plants using Agrobacterium-mediated DNA transfer. Nature Biotechnology, Vol.6, (1988), pp. 915-922, ISSN 1087-0156

Hiraga, S.; Minakawa, H.; Takahashi, K.; Takahashi, R.; Hajika, M.; Harada, K. \& Ohtsubo, N. (2007). Evaluation of somatic embryogenesis from immature cotyledons of Japanese soybean cultivars. Plant Biotechnology, v.24, No. 4, (September, 2007), p.435-440, ISSN 1342-4580

Hoffmann, N.; Nelson, R.L. \& Korban S.S. (2004). Influence of media components and pH on somatic embryo induction in three genotypes of soybean. Plant Cell, Tissue and Organ Culture, Vol.77, No.2, (2004), pp. 157-163, ISSN 0167-6857

Homrich, M.S.; Passaglia, L.M.P.; Pereira, J.F.; Bertagnolli, P.F.; Pasquali, G.; Zaidi, M.A.; Altosaar, I. \& Bodanese-Zanettini, M.H. (2008). Resistance to Anticarsia gemmatalis Hübner (Lepidoptera, Noctuidae) in transgenic soybean (Glycine max (L) Merrill Fabales, Fabaceae) cultivar IAS5 expressing a modified Cry1Ac endotoxin. Genetics and Molecular Biology, Vol.31, No.2, (2008), pp. 522-531, ISSN $1415-4757$ 
Hong, H.P.; Zhang, H.; Olhoft, P.; Hill, S.; Wiley, H.; Toren, E.; Hillebrand, H.; Jones, T. \& Cheng, M. (2007). Organogenic callus as the target for plant regeneration and transformation via Agrobacterium in soybean (Glycine max (L) Merr). In Vitro Cellular and Developmental Biology-Plant, Vol.43, No.6, (2007), pp. 558-568, ISSN 1054-5476

Hsu, F.C. \& Obendorf, R.L. (1982). Compositional analysis of in vitro matured soybean seeds. Plant Science Letters, Vol.27, No.2, (October 1982), pp. 129-135, ISSN 01689452

Kermode, A.R. (1990). Regulatory mechanism involved in the transition from seed development to maturation Critical Reviews in Plant Sciences, Vol.9, (1990), pp. 155195, ISSN 0735-2689

Kerns, H.R.; Barwale, V.B. \& Meyer, M.M. (1986). Correlation of cotyledonary node shoot proliferation and somatic embryoid development in suspension cultures of soybean [Glycine max (L.) Merr.]. Plant Cell Reports, Vol.5, No.2, (1986), p. 140-143, ISSN 0721-7714

Kiss, E.; Heszky, L.E.; Gyulai, G.; Horváth, H.S. \& Csillag, A. (1991). Neomorph and leaf differentiation as alternative morphogenetic pathways in soybean tissue culture. Acta Biologica Hungarica, Vol. 42, No.4, (1991), pp. 313-321, ISSN 0236-5383

Kita Y.; Nishizawa K,; Takahashi M.; Kitayama M. \& Ishimoto M. (2007). Genetic improvement of the somatic embryogenesis and regeneration in soybean and transformation of the improved breeding lines. Plant Cell Reports, vol.26, No. 4, (April, 2007), pp. 439-447, ISSN 1432-203X

Ko, T.S.; Lee, S.; Farrand, S.K. \& Korban, S.S. (2004). A partially disarmed vir helper plasmid, pKYRT1, in conjunction with 2,4-dichlorophenoxyacetic acid promotes emergence of regenerable transgenic somatic embryos from immature cotyledons of soybean. Planta, Vol.218, No.4, (February), pp. 536-541, ISSN 0032-0935

Ko, T.S.; Lee, S.; Krasnyanski, S. \& Korban, S.S. (2003). Two critical factors are required for efficient transformation of multiple soybean cultivars: Agrobacterium strain and orientation of immature cotyledonary explant. Tag Theoretical and Applied Genetics, Vol.107, No.3, (2003), pp. 439-447, ISSN 0040-5752

Kohli, A.; Twyman, R.M.; Abranches, R.; Weget, E.; Stoger, E. \& Christou, P. (2003). Transgene integration, organization and interaction in plants. Plant Molecular Biology, Vol.52, No.2, (2003), pp. 247-258, ISSN 0167-4412

Komatsuda, T. \& Ko, S.W. (1990). Screening of soybean (Glycine max (L.) Merrill) genotypes for somatic embryo production from immature embryo. Japanese Journal of Breeding, Vol.40, (1990), pp. 249-251, ISSN 0536-3683

Komatsuda, T. \& Ohyama, K. (1988). Genotype of high competence for somatic embryogenesis and plant regeneration in soybean Glycine max. Theoretical and Applied Genetics, Vol. 75, No. 5, (1998), pp. 695-700, ISSN 0040-5752

Komatsuda, T., Kanebo, K., \& Oka, S. (1991). Genotype $\times$ sucrose interactions for somatic embryogenesis in soybean. Crop Science. Vol.31, No.2, (1991), pp. 333-337, ISSN 0011-183X

Körbes, A.P. \& Droste, A. (2005). Carbon sources and polyethylene glycol on soybean somatic embryo conversion. Pesquisa Agropecuária Brasileira, Vol.40, No.3, (March 2005), pp. 211-216, ISSN 0100-204X 
Kumari, B.D.R.; Settu, A. \& Sujatha, G. (2006). Somatic embryogenesis and plant regeneration in soybean. Indian Journal of Biotechnology, Vol.5, (April 2006), p. 243245, ISSN 0972-5849

Lakshmanan P. \& Taji A. (2000). Somatic Embryogenesis in Leguminous Plants. Plant Biology, Vol.2, No.2, (March 2000), pp. 136-148, ISSN 1435-8603

Lazzeri, P.A., Hildebrand, D.F., Sunega, J., Williams, E.G. \& Collins, G.B. (1988). Soybean somatic embryogenesis: interactions between sucrose and auxin. Plant Cell Reports, Vol.7, (1988), pp. 517-520, ISSN 0721-7714

Lazzeri, P.A.; Hildebrand, D.F. \& Collins, G.B. (1987). Soybean somatic embryogenesis: effects of hormones and culture manipulations. Plant Cell, Tissue and Organ Culture, Vol.10, (1987), pp. 197-208, ISSN 0167-6857

Lazzeri, P.A.; Hilderbrand, D.F. \& Collins, G.B. (1985). A procedure for plant regeneration from immature cotyledon tissue of soybean. Plant Molecular Biology Reporter, Vol.3, No.4, (Winter 1985), pp. 160-167, ISSN 0735-9640

Li, X.Y.; Huang, F.H.; Murphy, B. \& Gbur Junior, E.E. (1998). Polyethylene glycol and maltose enhance somatic embryo maturation in loblolly pine (Pinus taeda L.). In Vitro Cellular and Developmental Biology-Plant, Vol.34, (1998), pp. 22-26, ISSN 1071-2690

Li, Z.; Xing, A.; Moon, B.P.; McCardell, R.P.; Mills, K. \& Falco, S.C. (2009). Site-Specific Integration of Transgenes in Soybean via Recombinase-Mediated DNA Cassette Exchange. Plant Physiology, Vol.151, No.3, (2009), pp. 1087-1095, ISSN 00320889

Lippmann, B. \& Lippmann, G. (1984). Induction of somatic embryos in cotyledonary tissue of soybean, Glycine max L. Merr. Plant Cell Reports, Vol.185, No.3, (September 1984), pp. 215-218, ISSN 0721-7714

Lippmann, B. \& Lippmann, G. (1993). Soybean embryo culture: factors influencing plant recovery from isolated embryos. Plant Cell, Tissue and Organ Culture, Vol.32, No.1, (1993), pp. 83-90, ISSN 0167-6857

Liu, S.J.; Wei, Z.M. \& Huang, J.Q. (2008). The effect of co-cultivation and selection parameters on Agrobacterium-mediated transformation of Chinese soybean varieties. Plant Cell Reports, Vol.27, No.3, (2008), pp. 489-498, ISSN 0721-7714

Liu, W.; Moore, P.J. \& Collins, G.B. (1992). Somatic embryogenesis in soybean via somatic embryo cycling. In Vitro Cellular and Developmental Biology-Plant, Vol.28, No.3, (July 1992), pp. 153-160, ISSN 1054-5476

Maheswaran, G. \& Williams, E.G. (1984). Direct somatic embryoid formation on immature embryos of Trifolium repens, T. pretense and Medicago sativa, and rapid clonal propagation of T. repens. Annals of Botany, Vol.54, (1984), pp. 201-211, ISSN 03057364

Mauro, A.O.O.; Pfeiffer, T.W. \& Collins, G.B. (1995). Inheritance of soybean susceptibility to Agrobacterium tumefaciens and its relationship to transformation. Crop Science, Vol.35, No.4, (1995), pp. 1152-1156, ISSN 0011-183X

McCabe, D.E.; Swain, W.F.; Martinell, B.J. \& Christou, P. (1988). Stable transformation of soybean (Glycine max) by particle acceleration. Nature Biotechnology, Vol.6, (1988), pp. 923-926, ISSN 1087-0156 
Merkle, S.A.; Parrott, W.A. \& Flinn, B.S. (1995). Morphogenic aspects of somatic embryogenesis. In: In vitro embryogenesis in plants, T.A. Thorpe, (Ed.), 155-203, Kluwer Academic, ISBN 0-7923-3149-4, Dordrecht, Netherlands

Meurer, C.A.; Dinkins, R.D.; Redmond, C.T.; Mcallister, K.P.; Tucker, D.T.; Walker, D.R.; Parrott, W.A.; Trick, H.N.; Essig, J.S.; Frantz, H.M.; Finer, J.J. \& Collins, G.B. (2001). Embryogenic response of multiple soybean [Glycine max (L.) Merr.] cultivars across three locations. In Vitro Cellular and Developmental Biology-Plant, Vol.37, No.67, (January-February 2001), pp. 62-67, ISSN 1054-5476

Miklos, J.A.; Alibhai, M.F.; Bledig, S.A.; Connor-Ward, D.C.; Gao, A.G.; Holmes, B.A.; Kolacz, K.H.; Kabuye, V.T.; MacRae, T.C.; Paradise, M.S.; Toedebusch, A.S. \& Harrison, L.A. (2007). Characterization of soybean exhibiting high expression of a synthetic Bacillus thuringiensis cry1A transgene that confers a high degree of resistance to Lepidopteran pests. Crop Science, Vol.47, (2007), pp. 148-157, ISSN 0011-183X

Murashige, T. \& Skoog, F. (1962). A revised medium for rapid growth and bio assays with tobacco tissue cultures. Physiologia Plantarum, Vol. 15, (1962), pp. 473-497, ISSN 0031-9317

Parrott, W.A.; Dryden, G.; Vogt, S.; Hildebrand, D.F.; Collins, G.B. \& Williams, E.G. (1988). Optimization of somatic embryogenesis and embryo germination in soybean. In Vitro Cellular and Development Biology-Plant, Vol.24, (1988), pp. 817-820, ISSN 1071-2690

Parrott, W.A.; Durham, R.E. \& Bailey, M.A. (1995). Somatic embryogenesis in legumes. In: Biotechnology in Agriculture and Forestry, Somatic Embryogenesis and Synthetic Seed II, Y. P. S. Bajaj, (Ed.), 199-227, Springer-Verlag, ISBN 0-387-57449-2-X, Berlin

Parrott, W.A.; Hoffman, L.M.; Hildebrand, D.F.; Williams, E.G. \& Collins, G.B. (1989). Recovery of primary transformants of soybean. Plant Cell Reports, Vol.7, No.8, (1989), pp. 615-617, ISSN 0721-7714

Parrott, W.A.; Williams E.G.; Hildebrand, D.F. \& Collins, G.B. (1989). Effect of genotype on somatic embryogenesis from immature cotyledons of soybean. Plant Cell, Tissue and Organ Culture, Vol. 16, No. 1, (1989) pp. 15-21, ISSN 0167-6857

Paz, M.M.; Martinez, J.C.; Kalvig, A.B.; Fonger, T.M. \& Wang, K. (2006). Improved cotyledonary node method using an alternative explant derived from mature seed for efficient Agrobacterium-mediated soybean transformation. Plant Cell Reports, Vol.25, No.3, (2006), pp. 206-213, ISSN 0721-7714

Pitzschke, A. \& Hirt, H. (2010). New insights into an old story: Agrobacterium-induced tumour formation in plants by plant transformation. The EMBO Journal, Vol.29, No.6, (February 2010), pp. 1021-1032, ISSN 0261-4189

Raghavan, V. (1986). Embryogenesis in Angiosperms. A Developmental and Experimental Study. Raghavan, V. ISBN 0-521-26771-4, Cambridge, U.K., Cambridge University Press

Ranch, J.P.; Oglesby, L. \& Zielinski, A.C. (1985). Plant regeneration from embryo-derived tissue culture of soybeans. In Vitro Cellular and Developmental Biology-Plant, Vol.21, No.11, (1985), pp. 653-658, ISSN 1071-2690

Reinert, J. (1958). Morphogenese und ihre Kontrolle an Gewebekulturen aus Karotten. Naturwissenschaften, Vol.45, (1958), pp. 344-349, ISSN 0028-1042 
Rock, C.D. \& Quatrano, R.S. (1995). The role of hormones during seed development. In: Plant hormones: physiology, biochemistry and molecular biology, P.J. DAVIES, (Ed.), pp. 671-697, Kluwer Academic, ISBN 0-7923-2985-6, Dordrecht, Netherlands

Rodrigues, L.R.; Oliveira, J.M.S.; Mariath, J.E.A. \& Bodanese-Zanettini, M.H. (2005). Histology of embryogenic responses in soybean anther culture. Plant Cell, Tissue and Organ Culture, Vol.80, No.2, (February 2005), pp. 129-137, ISSN 0167-6857

Rosenberg, L.A. \& Rinne, R.W. (1986). Moisture loss as a prerequisite for seedling growth in soybean seeds (Glycine max L. Merr.). Journal of Experimental Botany, Vol.37, No.11, (1986), pp. 1663-1674, ISSN 0022-0957

Rosenberg, L.A. \& Rinne, R.W. (1988). Protein synthesis during natural and precocious soybean seed (Glycine max L. Merr.) maturation. Plant Physiology, Vol.87, No.2, (June 1988), pp. 474-478, ISSN 0032-0889

Samoylov, V.M.; Tucker, D.M. \& Parrott, W.A. (1998b). A liquid medium-based protocol for rapid regeneration from embryogenic soybean cultures. Plant Cell Reports, Vol.18, (1998), pp. 49-54, ISSN 0721-7714

Samoylov, V.M; Tucker, D.M. \& Parrott, W.A. (1998a). Soybean [Glycine max (L.) Merrill] embryogenic cultures: the role of sucrose and total nitrogen content on proliferation. In Vitro Cellular and Developmental Biology-Plant, Vol.34, (JanuaryMarch 1998), pp. 8-13, ISSN 1071-2690

Sanford, J.C. (1988). The biolistic process. Trends Biotechnology, Vol.6, No.12, (December 1988), pp. 299-302, ISSN 0167-7799

Sanford, J.C. (1990). Biolistic plant transformation. Physiologia Plantarum, Vol.79, No.1, (May 1990), pp. 206-209, ISSN 0031-9317

Santarém, E.R. \& Finer, J.J. (1998). Transformation of soybean [Glycine max (L.) Merrill] using proliferative embryogenic tissue maintained on semi-solid medium. In Vitro Cellular and Developmental Biology-Plant, Vol.35, (November-December 1998), pp. 451-455, ISSN 1071-2690

Santarém, E.R.; Pelissier, B. \& Finer, J.J. (1997). Effect of explant orientation, pH, solidifying agent and wounding on initiation of soybean somatic embryos. In Vitro Cellular and Developmental Biology-Plant, Vol.33, No.1, (January 1997), pp. 13-19, ISSN 1071-2690

Santos, K.G.B.; Mariath, J.E.A.; Moço, M.C.C. \& Bodanese-Zanettini, M.H. (2006). Somatic Embryogenesis from Immature Cotyledons of Soybean (Glycine max (L.) Merr.): Ontogeny of Somatic Embryos. Brazilian Archives of Biology and Technology, Vol. 49, No.1, (January 2006), pp. 49-55, ISSN 1516-8913

Santos, K.G.B.; Mundstock, E.; Bodanese-Zanettini, M.H. (1997). Genotype-specific normalization of soybean somatic embryogenesis through the use of an ethylene inhibitor. Plant Cell Reports, Vol. 16, No. 12, (June, 1997), pp. 859-864, ISSN 07217714

Saravitz, C.H. \& Raper, C.D.Jr. (1995). Responses to sucrose and glutamine by soybean embryos grown in vitro. Physiologia Plantarum, Vol.93, (1995), pp. 799-805, ISSN 0031-9317

Sato, S.; Newell, C.; Kolacz, K.; Tredo, L.; Finer, J. \& Hinchee, M. (1993). Stable transformation via particle bombardment in two different soybean regeneration systems. Plant Cell Reports, Vol.12, No.7-8, (1993), pp. 408- 413, ISSN 0721-7714 
Schmidt, M.A.; LaFayette, P.R.; Artelt, B.A. \& Parrott, W.A. (2008). A comparison of strategies for transformation with multiple genes via microprojectile-mediated bombardment. In Vitro Cellular and Developmental Biology-Plant, Vol. 44, No.3, (2008), pp. 162-168, ISSN 1071-2690

Schmidt, M.A.; Tucker, D.M.; Cahoon, E.B. \& Parrott, W.A. (2005). Towards normalization of soybean somatic embryo maturation. Plant Cell Reports, Vol.24, (2005), pp. 383391, ISSN 1432-203X

Sharma, K. K. \& Thorpe, T. A. (1995). Asexual Embryogenesis in Vascular Plants in Nature, In: In Vitro Embryogenesis in Plants, T.A.Thorpe, (Ed.), 17-72, Kluwer Academic, ISBN 0-7923-3149-4, Dordrecht, Netherlands

Sharp, W.R., Evans D.A. \& Sondahl, MR. (1982). Application of somatic embryogenesis to crop improvement. In: Plant tissue culture 1982. Proceedings of the Fifth International Congress of Plant Tissue Culture, A. Fujiwara, (Ed), 759-762, Japanese Association for Plant Tissue Culture, Maruzen, Tokyo

Simmonds, D.H. \& Donaldson, P.A. (2000). Genotype screening for proliferative embryogenesis and biolistic transformation of short-season soybean genotypes. Plant Cell Reports, Vol. 19, No. 5, (2000), pp. 485-490, ISSN 0721-7714

Smith, D.L. \& Krikorian, A.D. (1989). Release of somatic embryogenic potential from excised zygotic embryos of carrot and maintenance of proembryonic cultures in hormonefree medium. American Journal of Botany, Vol.76, No.12, (1989), pp. 1832-1840, ISSN 0002-9122

Somers, D.A.; Samac, D.A. \& Olhoft, P.M. (2003). Recent Advances in Legume Transformation. Plant Physiology, Vol. 131, No.3, (March 2003), pp. 892-899, ISSN 0032-0889

Stewart Jr, C.N.; Adang, M.J.; All, J.N.; Boerma, H.R.; Cardineau, G.; Tucker, D. \& Parrott, W.A. (1996). Genetic transformation, recovery, and characterization of soybean (Glycine max [L.] Merrill) transgenic for a synthetic Bacillus thuringiensis CRY1A(c) gene. Plant Physiology, Vol.112, No.1, (September 1996), pp. 121-129, ISSN 00320889

Thomas, T.D. (2008). The role of activated charcoal in plant tissue culture. Biotechnology Advances, Vol.26, (August 2008), pp. 618-631, ISSN 0734-9750

Thompson, J.F.; Madison, J.T. \& Muenster, A.-M.E. (1977). In vitro culture of immature cotyledons of soya bean (Glycine max L. Merr.). Annals of Botany, Vol.41, No.1, (1977), pp. 29-39, ISSN 0305-7364

Tian, L.N. \& Brown, D.C.W. (2000). Improvement of soybean somatic embryo development and maturation by abscisic acid treatment. Canadian Journal of Plant Science, Vol.80, (2000), pp. 721-276, ISSN 0008-4220

Tomlin, E.S.; Branch, S.R.; Chamberlain, D.; Gabe, H., Wright, M.S. \& Stewart, C.N. (2002). Screening of soybean, Glycine max (L.) Merrill, lines for somatic embryo induction and maturation capability from immature cotyledons. In Vitro Cellular and Developmental Biology-Plant, Vol.38, (November-December 2002), pp. 543-548, ISSN 1071-2690

Trick, H.N. \& Finer, J.J. (1997). SAAT: sonication-assisted Agrobacterium-mediated transformation. Transgenic Research, Vol.6, (1997), pp. 329-336, ISSN 0962-8819 
Trick, H.N. \& Finer, J.J. (1998). Sonication-assisted Agrobacterium-mediated transformation of soybean (Glycine max) embryogenic suspension culture tissue. Plant Cell Reports, Vol.17, (1998), pp. 482-488, ISSN 0721-7714

Trick, H.N.; Dinkins, R.D.; Santarém, E.R.; Di, R.; Samoylov, V.; Meurer, C.A.; Walker, D.R.; Parrott, W.A.; Finer, J.J. \& Collins, G.B. (1997). Recent advances in soybean transformation. Plant Tissue Culture and Biotechnology, Vol.3, No.1, (March 1997), pp. 9-24, ISSN 1817-3721

Vergara, R.; Verde, F.; Pitto, L.; LoSchiavo, F. \& Terzi, M. (1990). Reversible variations in the methylation pattern of carrot DNA during somatic embryogenesis. Plant Cell Reports, Vol.8, No.12, (1990), pp. 697-701, ISSN 0721-7714

Vianna, G.R.; Aragão; F.J.L. \& Rech, E.L. (2011). A minimal DNA cassette as a vector for genetic transformation of soybean (Glycine max). Genetics and Molecular Research, Vol.10, No.1, (March 2011), pp. 382-390, ISSN 1676-5680

Walker, D.R. \& Parrott, W.A. (2001). Effect of polyethylene glycol and sugar alcohols on soybean somatic embryo germination and conversion. Plant Cell, Tissue and Organ Culture, Vol.64, No.1, (January 2001), pp. 55-62, ISSN 0167-6857

Wang, G. \& Xu, Y. (2008). Hypocotyl-based Agrobacterium-mediated transformation of soybean (Glycine max) and application for RNA interference. Plant Cell Reports, Vol.27, No.7, (2008), pp. 1177-1184, ISSN 0721-7714

Weber, R.L.M.; Körber, A.P.; Baldasso, D.A.; Callegari-Jacques, S.M.; Bodanese-Zanettini, M.H. \& Droste, A. (2007). Beneficial effect of abscisic acid on soybean somatic embryo maturation and conversion into plants. Plant Cell Culture and Micropropagation, Vol. 3, No. 1, (2007), pp. 1-9, ISSN 1808-9909

Wiebke, B.; Ferreira, F.; Pasquali, G.; Bodanese-Zanettini, M.H. \& Droste, A. (2006). Influence of antibiotics on embryogenic tissue and Agrobacterium tumefaciens suppression in soybean genetic transformation. Bragantia, Vol.65, No.4, (2006), pp. 543-551, ISSN 0006-8705

Wiebke-Strohm, B.; Droste, A.; Pasquali, G.; Osorio, M.B.; Bücker-Neto, L.; Passaglia, L.M.P.; Bencke, M.; Homrich, M.S.; Margis-Pinheiro, M. \& Bodanese-Zanettini, M.H. (2011). Transgenic fertile soybean plants derived from somatic embryos transformed via the combined DNA-free particle bombardment and Agrobacterium system. Euphytica, Vol.177, No.3, (2011), pp. 343-354, ISSN 00142336

Williams, E. G. \& Maheswaran, G. (1986). Somatic embryogenesis: factors influencing coordinated behavior of cells as an embryogenic group. Annals of Botany, Vol.57, No.4, (April 1986), pp. 443-462, ISSN 0305-7364

Wright, M.S.; Launis, K.L.; Novitzky, R.; Duesiing, J.H. \& Harms, C.T. (1991). A simple method for the recovery of multiple fertile plants from individual somatic embryos of soybean [Glycine max (L.) Merrill]. In Vitro Cellular and Developmental BiologyPlant, Vol.27, (1991), pp. 153-157, ISSN 1071-2690

Wu, C.; Chiera, J.M.; Ling, P.P. \& Finer, J.J. (2008). Isoxaflutole treatment leads to reversible tissue bleaching and allows for more effective detection of GFP in transgenic soybean tissues. In Vitro Cellular and Developmental Biology-Plant, Vol.44, No.6, (2008), pp. 540-547, ISSN 1054-5476 
Xing, A.; Moon, B.P.; Mills, K.M.; Falco, S.C. \& Li, Z. (2010). Revealing frequent alternative polyadenylation and widespread low-level transcription read-through of novel plant transcription terminators. Plant Biotechnology Journal, Vol.8, No.7, (September 2010), pp. 772-782, ISSN 1467-7644

Yan, B.; Reddy, M.S.S.; Collins, G.B. \& Dinkins, R.D. (2000). Agrobacterium tumefaciens mediated transformation of soybean [Glycine max (L) Merrill] using immature zygotic cotyledon explants. Plant Cell Reports, Vol.19, No.11, (2000), pp. 1090-1097, ISSN 0721-7714

Yang, C.; Zhao, T.; Yu, D. \& Gai J. (2009). Somatic embryogenesis and plant regeneration in Chinese soybean (Glycine max (L.) Merr.)-impacts of mannitol, abscisic acid, and explants age. In Vitro Cellular and Developmental Biology-Plant, Vol. 45, No. 2, (April 2009), pp. 180-181, ISSN 1054-5476 


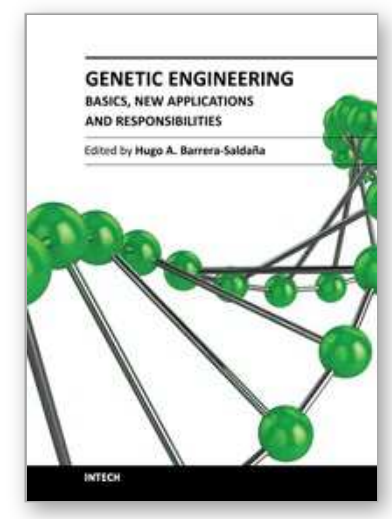

\author{
Genetic Engineering - Basics, New Applications and \\ Responsibilities \\ Edited by Prof. Hugo A. Barrera-Saldaña
}

ISBN 978-953-307-790-1

Hard cover, 256 pages

Publisher InTech

Published online 18, January, 2012

Published in print edition January, 2012

Leading scientists from different countries around the world contributed valuable essays on the basic applications and safety, as well as the ethical and moral considerations, of the powerful genetic engineering tools now available for modifying the molecules, pathways, and phenotypes of species of agricultural, industrial and even medical importance. After three decades of perfecting such tools, we now see a refined technology, surprisingly unexpected applications, and matured guidelines to avoid unintentional damage to our and other species, as well as the environment, while trying to contribute to solve the biological, medical and technical challenges of society and industry. Chapters on thermo-stabilization of luciferase, engineering of the phenylpropanoid pathway in a species of high demand for the paper industry, more efficient regeneration of transgenic soybean, viral resistant plants, and a novel approach for rapidly screening properties of newly discovered animal growth hormones, illustrate the state-of-the-art science and technology of genetic engineering, but also serve to raise public awareness of the pros and cons that this young scientific discipline has to offer to mankind.

\title{
How to reference
}

In order to correctly reference this scholarly work, feel free to copy and paste the following:

Beatriz Wiebke-Strohm, Milena Shenkel Homrich, Ricardo Luis Mayer Weber, Annette Droste and Maria Helena Bodanese-Zanettini (2012). Strategies for Improvement of Soybean Regeneration via Somatic Embryogenesis and Genetic Transformation, Genetic Engineering - Basics, New Applications and Responsibilities, Prof. Hugo A. Barrera-Saldaña (Ed.), ISBN: 978-953-307-790-1, InTech, Available from: http://www.intechopen.com/books/genetic-engineering-basics-new-applications-and-responsibilities/strategiesfor-improvement-of-soybean-regeneration-via-somatic-embryogenesis-and-genetic-transformat

\section{INTECH}

open science | open minds

\author{
InTech Europe \\ University Campus STeP Ri \\ Slavka Krautzeka 83/A \\ 51000 Rijeka, Croatia \\ Phone: +385 (51) 770447 \\ Fax: +385 (51) 686166 \\ www.intechopen.com
}

\author{
InTech China \\ Unit 405, Office Block, Hotel Equatorial Shanghai \\ No.65, Yan An Road (West), Shanghai, 200040, China \\ 中国上海市延安西路65号上海国际贵都大饭店办公楼 405 单元 \\ Phone: +86-21-62489820 \\ Fax: +86-21-62489821
}


(C) 2012 The Author(s). Licensee IntechOpen. This is an open access article distributed under the terms of the Creative Commons Attribution 3.0 License, which permits unrestricted use, distribution, and reproduction in any medium, provided the original work is properly cited. 